\title{
Reactivity of amniotic fluid alpha-fetoprotein with concanavallin $A$ in diagnosis of neural tube defects
}

\author{
CAROL J SMITH， PHILIP C KELLEHER， LUC BÉLANGER， LOUIS DALLAIRE
}

British Medical fournal, 1979, 1, 920-921

\section{Summary and conclusions}

Alpha-fetoprotein (AFP) concanavallin-A-affinity molecular variant patterns were determined in amniotic fluid samples from 10 pregnancies complicated by anencephaly (6), spina bifida (1), Turner's syndrome (1), osteogenesis imperfecta congenita (1), and fetal death (1) and 20 normal pregnancies between 14.6 and 25.5 weeks of gestation. With the exception of one anencephalic pregnancy, the AFP concentrations in samples from women with a fetal abnormality were more than 5 SD above normal for gestational age. In every case, however, the proportion of total amniotic fluid AFP that was not reactive with concanavallin $A$ was significantly smaller in the presence of a fetal abnormality (mean $2 \%$ ) than when the fetus was normal (mean $20 \%$ ).

The results suggest that measuring the amount of concanavallin-A-non-reactive amniotic fluid AFP will be a valuable test for diagnosing fetal abnormality, especially when an increase in total amniotic fluid AFP concentration is equivocal or gestational age is uncertain.

\section{Introduction}

Increased alpha-fetoprotein (AFP) concentrations in amniotic fluid were first shown to be associated with anencephaly and spina bifida in 1972. ${ }^{1}$ Raised concentrations were then found in other fetal abnormalities. ${ }^{2}$ Amniotic fluid AFP concentrations, however, vary with the duration of pregnancy, so that the diagnosis of fetal malformations depends on accurate gestational aging.

AFP from man and rats consists of two molecular variants based on their reactivity with concanavallin A. ${ }^{3}$ Proportions of total AFP that do not react with concanavallin A differ in fetal serum and amniotic fluid ${ }^{5}{ }^{5}: 2-6 \%$ of fetal serum AFP and $15-45 \%$ of amniotic fluid AFP does not react with concanavallin A. ${ }^{5}$ Increased amounts of AFP in amniotic fluid in the presence of neural tube defects are thought to result from transudation of fetal serum across exposed fetal membranes. ${ }^{6}{ }^{7}$ We have therefore measured the proportions of concanavallin-A-nonreactive AFP in amniotic fluid samples from normal pregnancies and pregnancies in which there were fetal abnormalities as a test to detect leakage of fetal serum into the amniotic cavity.

Department of Medicine, College of Medicine, University of Vermont, Burlington, Vermont 05405, USA

CAROL J SMITH, PHD, research assistant professor in medicine

PHILIP C KELLEHER, MD, associate professor of medicine

Molecular Biology Laboratory, Centre de Recherche, L'Hôtel-Dieu de Quebec, Quebec, Quebec G1R 2J6, Canada

LUC BÉLANGER, MD, PHD, professor of biochemistry

Section of Medical Genetics, Hôpital Ste Justine, Montreal, Quebec H3T 1C5, Canada

LOUIS DALLAIRE, MD, PHD, chief of section of medical genetics

\section{Materials and methods}

Amniotic fluid samples from 10 pregnancies complicated by anencephaly and other fetal abnormalities and 20 normal pregnancies between 14.6 and 25.5 weeks of gestation were obtained at St Justine's Hospital, Montreal (LD), and stored at $-60^{\circ} \mathrm{C}$. The investigation was conducted as a retrospective, double-blind study. Samples were coded with use of a table of randomly assorted digits, and column chromatography (CJS and PCK) and AFP measurements (LB) were performed in random order.

Chromatography on concanavallin-A-agarose (Pharmacia Fine Chemicals) was carried out as described ${ }^{8}$ with the following modifications. Aliquots $(0.1$ and $0.2 \mathrm{ml})$ of each amniotic fluid sample were applied to columns of $5 \mathrm{ml}$ bed volume of fresh concanavallin-Aagarose. Two fractions were collected with the equilibrating buffer, a $3.0 \mathrm{ml}$ void fraction and the $5.0 \mathrm{ml}$ containing the concanavallin-Anon-reactive proteins. An additional $5 \mathrm{ml}$ fraction was eluted before adding glucose to the equilibrating buffer to a final concentration of $0 \cdot 1 \mathrm{~mol} / 1(18 \mathrm{~g} / \mathrm{l})$. Proteins reactive with concanavallin A were eluted in $15 \mathrm{ml}$. The capacity of the concanavallin-A-agarose matrix to bind human amniotic fluid proteins was at least eight times greater than the amount of protein applied to the columns. On rechromatography all of the concanavallin-A-non-reactive proteins in $1.5 \mathrm{ml}$ aliquots of amniotic fluid eluted in the non-reactive fraction.

The AFP standard was prepared and the AFP measured in the amniotic fluid samples and four chromatographic fractions by radioimmunoassay. ${ }^{9}$ Neither chromatographic buffer affected the accuracy of the radioimmunoassay, as indicated by complete recovery (mean $100 \cdot 4 \%$ ) of AFP added to random chromatographic fractions. The AFP concanavallin-A-affinity molecular variant pattern was expressed as the percentage of total amniotic fluid AFP applied to the column that was not bound by the concanavallin-A-agarose matrix. ${ }^{8}$ Total protein concentrations were determined by the method of Lowry et al. ${ }^{10}$

\section{Results}

The table gives the amniotic fluid AFP concentrations and AFP concanavallin-A-affinity molecular variant patterns in the samples from the two groups. Total protein concentrations were above normal in five of the abnormal pregnancies. Amniotic fluid AFP concentrations greatly exceeded the mean values expected for gestational age ${ }^{11}$ except in case 8. Without exception, however, the percentage of total amniotic fluid AFP not reactive with concanavallin A was lower in the presence of a fetal abnormality (mean $2 \cdot 4 \%$ ) than when the fetus was

Amniotic fluid AFP concentrations and AFP concanavallin- $A$-affinity molecular variant patterns in presence of fetal abnormalities

\begin{tabular}{|c|c|c|c|c|c|}
\hline $\begin{array}{l}\text { Case } \\
\text { No }\end{array}$ & Fetal abnormality & $\begin{array}{c}\text { Gesta- } \\
\text { tional } \\
\text { age } \\
\text { (weeks) }\end{array}$ & $\begin{array}{c}\text { Total } \\
\text { protein } \\
\text { concen- } \\
\text { tration } \\
(\mathbf{g} / \mathbf{l})\end{array}$ & $\begin{array}{l}\text { AFP } \\
\text { concen- } \\
\text { tration } \\
(\mathrm{mg} / \mathrm{l})\end{array}$ & $\begin{array}{c}\% \text { Con- } \\
\text { canavallin- } \\
\text { A-non- } \\
\text { reactive } \\
\text { AFP* }\end{array}$ \\
\hline $\begin{array}{r}1 \\
2 \\
3 \\
4 \\
5 \\
6 \\
7 \\
8 \\
9 \\
10\end{array}$ & $\begin{array}{l}\text { Spina bifida } \\
\text { Anencephaly } \\
\text { Fetal death } \\
\text { Anencephaly } \\
\text { Turner's syndrome with hygroma } \\
\text { Anencephaly } \\
\text { Anencephaly } \\
\text { Anencephaly } \\
\text { Anencephaly } \\
\text { Osteogenesis imperfecta congenita }\end{array}$ & $\begin{array}{l}14 \cdot 6 \\
16 \cdot 0 \\
17 \cdot 5 \\
18 \cdot 0 \\
18 \cdot 5 \\
20 \cdot 0 \\
22 \cdot 0 \\
23 \cdot 0 \\
25 \cdot 0 \\
25 \cdot 5\end{array}$ & $\begin{array}{r}3 \cdot 2 \\
9 \cdot 6 \\
11.9 \\
5 \cdot 7 \\
10 \cdot 9 \\
9 \cdot 1 \\
6 \cdot 6 \\
3 \cdot 3 \\
6 \cdot 0 \\
14 \cdot 8\end{array}$ & $\begin{array}{r}65 \\
480 \\
300 \\
220 \\
1200 \\
180 \\
61 \\
12 \\
62 \\
400\end{array}$ & $\begin{array}{l}5 \cdot 2 \\
3 \cdot 2 \\
1.9 \\
1 \cdot 9 \\
1 \cdot 2 \\
1.5 \\
3 \cdot 3 \\
2 \cdot 2 \\
2 \cdot 5 \\
1 \cdot 4\end{array}$ \\
\hline
\end{tabular}

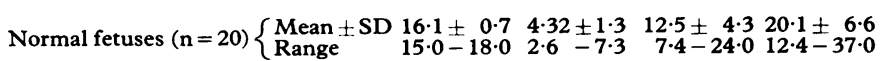

*Percentage of total amniotic fluid AFP not bound by concanavallin-A-agarose matrix; (ng concanavallin-A-non-reactive AFP/ng AFP applied to column in $0.2 \mathrm{ml}$ aliquot of amniotic fluid) $\times 100$. 
normal (mean $20 \cdot 1 \%$ ). The difference in mean percentages between the two groups was highly significant $(P<0.001)$. The values listed in the table are based on the results of column chromatography of the $0.2 \mathrm{ml}$ aliquot of amniotic fluid, but differences of the same level of significance were obtained with values based on the $0 \cdot 1 \mathrm{ml}$ aliquot. The AFP concanavallin-A-affinity molecular variant patterns did not correlate with concentrations of either the total amniotic fluid protein or total amniotic fluid AFP. More important, the percentage of concanavallin-A-non-reactive AFP was not related to gestational age within the range of ages tested.

\section{Discussion}

Since the AFP concentration varies with the duration of pregnancy its use as a diagnostic index of neural tube defects may yield false-positive results. An observed value may be taken as normal if gestational age has been overestimated and abnormal if age has been underestimated. This difficulty is reflected in amniotic fluid AFP concentrations that are not normally distributed. ${ }^{11}$ Multiple monoamniotic pregnancy may also be associated with raised amniotic fluid AFP concentrations when the fetuses are normal. ${ }^{12}$ Some laboratories ${ }^{11}$ have therefore extended the normal range of AFP values to include $5 \mathrm{SD}$ above the mean.

Our table shows that leakage of fetal serum into the amniotic fluid was reflected by a change in the AFP concanavallin-Aaffinity molecular variant pattern. In normal amniotic fluid samples $12-37 \%$ of the AFP did not react with concanavallin A. Leakage of fetal serum, containing about $2 \%$ concanavallin-Anon-reactive AFP, reduced the proportion of concanavallin-Anon-reactive AFP in the amniotic fluid to $1 \cdot 2-5 \cdot 2 \%$. This observation is particularly important because the AFP concanavallin-A-affinity molecular variant pattern was independent of gestational age.

Case 8 shows the value of determining the AFP concanavallinA-affinity molecular variant patterns when the increase in amniotic fluid AFP concentration is equivocal. The fetus was anencephalic but the amniotic fluid AFP concentration was $12.0 \mathrm{mg} / 1$ at 23 weeks of gestation. This was less than $5 \mathrm{SD}$ above the mean expected for gestational age, yet the percentage of concanavallin-A-non-reactive AFP was clearly lower than normal. On the other hand, in two of the normal pregnancies at 16 weeks' gestation the amniotic fluid AFP concentrations were 19.0 and $24.0 \mathrm{mg} / \mathrm{l}$ - that is, between 2 and 3 SD above the mean expected for gestational age. The percentages of concanavallin-A-non-reactive AFP, however, were 14.9 and 17.9 respectively, which were comparable with the mean of 20.5 in the remaining 18 normal pregnancies. Thus in normal multiple monoamniotic pregnancies the percentage of concanavallin-Anon-reactive AFP would probably be normal even if the amniotic fluid AFP concentration and maternal serum AFP concentration were raised.

The abnormal pregnancies we studied comprised three cases of fetal malformation, one fetal death, and six cases of anencephaly. All were associated with defects in the integument or lymphatic (Turner's syndrome) or capillary (osteogenesis imperfecta congenita) development, and the decreased percentage of concanavallin-A-non-reactive AFP observed was consistent with leakage of fetal serum into the amniotic fluid. A raised amniotic fluid AFP concentration in osteogenesis imperfecta congenita has not apparently been reported, but is not unexpected in view of the thin skin and capillary fragility in such cases. ${ }^{13}$

For use in the clinical laboratory the determination of amniotic fluid AFP concanavallin-A-affinity molecular variant patterns may be simplified into two main steps. (1) Apply $0.2 \mathrm{ml}$ amniotic fluid to a $5 \mathrm{ml}$ bed volume column of concanavallin-Aagarose, discard the first $2.5 \mathrm{ml}$ eluted from the column with the equilibrating buffer (void fraction), and collect the next $7.5 \mathrm{ml}$ (concanavallin-A-non-reactive AFP) eluted with the equilibrating buffer. (2) Measure the AFP in the $7.5 \mathrm{ml}$ column eluate and amniotic fluid sample and calculate the percentage of total amniotic fluid AFP not bound by the concanavallin-A-agarose matrix:

ng concanavallin-A-non-reactive $\mathrm{AFP} / \mathrm{ml} \times 7 \cdot 5$

$\mathrm{ng}$ amniotic fluid $\mathrm{AFP} / \mathrm{ml} \times 0 \cdot 2$

We intend to see whether the abnormal AFP concanavallin-Aaffinity molecular variant patterns observed in amniotic fluid in cases of neural tube defects and certain other fetal malformations are reflected in maternal serum AFP.

We are grateful for the excellent technical help of Miss Diane Hamel and Miss Sharon O'Brien. The work was supported by USPHS research grant CA-15222 from the National Cancer Institute, National Institutes of Health (CJS and PCK), Medical Research Council of Canada grant MA-6478 (LB), and le Réseau de Médecine Génétique du Québec (LD). LB is a scholar of the Medical Research Council of Canada.

Requests for reprints should be addressed to: Dr Carol J Smith, Department of Medicine, University of Vermont, Given Building, Burlington, Vermont 05405, USA.

\section{References}

1 Brock, D J H, and Sutcliffe, R G, Lancet, 1972, 2, 197.

2 Brock, D J H, British Medical Bulletin, 1977, 32, 16.

${ }^{3}$ Smith, C J, and Kelleher, P C, Biochimica et Biophysica Acta, 1973, 317, 231.

4 Smith, C J, and Kelleher, P C, in Proceedings of 5th Meeting of International Research Group for Carcinoembryonic Proteins, 1977. In press.

5 Ruoslahti, E, in Proceedings of 6th Meeting of International Research Group for Carcinoembryonic Proteins, 1978. In press.

6 Brock, D J H, Lancet, 1976, 2, 345.

${ }^{7}$ Smith, C J, and Kelleher, P C, Teratology, 1977, 16, 71.

${ }^{8}$ Smith, C J, Morris, H P, and Kelleher, P C, Cancer Research, 1977, 37, 2651 .

${ }^{9}$ Bélanger, L, et al, Clinical Chemistry, 1976, 22, 198.

${ }^{10}$ Lowry, O H, et al, fournal of Biological Chemistry, 1951, 193, 265.

11 Kimball, M E, Milunsky, A, and Alpert, E, Obstetrics and Gynecology, 1977, 49, 532.

12 Seller, M J, Dumon, J E, and Vanderheyden, J S D, British Medical fournal, 1977, 1, 1600.

${ }^{13}$ Nora, J J, and Fraser, F C, Medical Genetics: Principles and Practice. Philadelphia, Lea and Febiger, 1974.

(Accepted 8 February 1979)

ONE HUNDRED YEARS AGO A remarkable experiment in the transplantation of teeth is recorded in the Gazette des Hopitaux, No 2, 1879. On July 30 th, $M$ Pietkiewicz extracted an anomalous right lower lateral incisor, which grew under the tongue in a young woman of twenty-six, and planted it in the upper jaw on the same side, in the alveolus of the lateral incisor, which he had just removed for extensive caries, and which was rotated congenitally on its axis. At the same time, by a special apparatus exercising constant pressure, he was able to bring back the right inferior canine into line. In spite of an accident, six weeks later, the experiment succeeded perfectly, the tooth becoming fixed with great firmness. It has been long known to be possible to replace a tooth just removed by another similar to it in regard to age, volume, form, etc, if recently extracted. Indeed, Professor Alquié of Montpellier showed, in 1858 , that a carious tooth could be replanted after resection of its decayed portion. But it is pointed out that, in $\mathbf{M}$ Pietkiewicz's case, there were very remarkable anatomical differences between a lower and upper lateral incisor. The roof of the former is finer, and flattened transversely and grooved; that of the upper is fuller and rounded. In fact, the fang of the lower by no means filled the upper alveolus, while at the same time it was considerably too long for it, requiring removal of a third of the crown to bring the edge into line with its neighbours. In spite of all this, the success was perfect, and suggested to the surgeon mentioned the possibility of utilising anomalous teeth for transplantation, even to replace others not anatomically analogous to them, the difference in shape being remedied by cutting and shaping with instruments. The teeth of other mammals might also, perhaps, be successfully employed for the same purpose. (British Medical fournal, 1879.) 